\title{
Do Information And Communications Technology (ICT) And Financial Development Contribute To Economic Diversification? Evidence From Sub-Saharan Africa
}

Oluwarotimi Ayokunnu Owolabi ( $\nabla$ oluwarotimi.owolabi@covenantuniversity.edu.ng )

Covenant University https://orcid.org/0000-0002-9996-3821

\section{Adedayo Oluseun Adedeji}

Federal University of Agriculture Abeokuta

\section{Busayo Aderounmu}

Covenant University

Asa-Ruth Oboko Oku

Covenant University

Toun Ogunbiyi

Covenant University

\section{Research}

Keywords: Information communication Technology (ICT), financial development, Economic diversification, Sub-Saharan Africa, Generalised Method of Moments

Posted Date: October 12th, 2021

DOI: https://doi.org/10.21203/rs.3.rs-952452/v1

License: @ (i) This work is licensed under a Creative Commons Attribution 4.0 International License. Read Full License 


\section{Abstract}

This study based on a panel of 37 Sub-Saharan Africa countries over the period of $2000-2018$ explores the effect of a number of ICT variables namely Fixed broad band, fixed line telephone, ICT imports, internet, mobile, and secure internet servers, and financial development measured by private sector domestic credit to GDP on economic diversification as measured by a computed Herfindahl Hirschman Index of Economic diversification. All data except rule of law were sourced from World Bank World Development Indicators, while rule of law was sourced from World Bank World Governance indicators. Model estimation was performed using pooled ordinary least squares regression, panel data fixed effects regression, and Generalised Method of Moments (GMM) regression. The results from findings indicated that the ICT variables, fixed line telephone, and ICT imports significantly reduced economic diversification, while internet use and mobile use were insignificant for boosting economic diversification, and fixed broadband and secure internet servers were insignificant in adversely affecting economic diversification. As regards financial development, it was insignificant in boosting economic diversification of SSA countries. The study recommended amongst others that Individuals in SSA countries should have improved access to ICT devices and governments' should ensure adequate provision of quality ICT infrastructure

JEL classification: C23, G10, G21, 011, 033, 055

\section{Introduction}

Low levels of economic development, together with low levels of most Information and communication technology measures prevalent in sub-saharan African countries as highlighted by development statistics of the World Bank suggest the significant importance of information technology for the promotion of economic development. Low levels of economic development are highlighted broadly by high poverty, unemployment and income inequality according to development literature (Todaro \& Smith, 2011), On the other hand, low levels of internet, mobile phone, broadband, secure servers, telephones, computers, collectively contributing to low levels of penetration of ICT and therefore ICT development emphasize the inadequacy of information technology devices as a sub-set of ICT in the sub-Saharan African countries. This is more so as the leap-frog hypothesis relating ICT to economic growth highlights the invaluable contribution of ICT to aiding less developed countries scale difficult hurdles on their path to the achievement of economic growth and development.

Related to economic development is economic diversification whose popular emphasis by development organizations as the World Bank may be traced to the advent of structural adjustment in developing countries in the late 80 s to early 90 s as it was anticipated that following successful reforms, developing country economies will be diversified. Economic diversification defined as the process of shifting an economy from a single source of income towards multiple sources from a growing range of sectors and markets has gradually overtime emerged as a pursuit of many of the developing economies of the world today, including sub-Saharan Africa countries. Borne out of its many significant benefits including positioning ailing economies for progress as erstwhile productive sectors as well as other sectors of the domestic economy previously underdeveloped are regenerated, economic diversification results in the achievement of an economically transformed nation reflected by incomes being realized by the country from a diversity of sources. Further reduced exposure of the domestic economy to adverse external economic influences, increased standards of living, increased employment, reduced poverty, reduced external dependence are features of an economically transformed economy following economic diversification and hence high levels of economic development may result.

Economists in countries across the world are generally in agreement that while there exists variation in the levels of economic development indicators across Sub-Saharan Africa countries, the bulk of Sub-Saharan African countries including major economies as Nigeria, Cote D'Ivoire, Kenya, South Africa are hindered from realizing their enormous economic potential on account of their inability to achieve economic diversification.

Economic diversification holds significant promise at boosting Africa's resilience and aiding the achievement of economic development as well as its sustainment over the longer term on the African continent (OECD, 2011). Robust and sustainable

Page 2/14 
growth may be better generated by economies that have a wide array of sectors undertaking a broad range of activities. The sectors working together may influence each other in the sectors individually and collectively contributing to economic diversification thus making a much more sizeable contribution to the achievement of economic diversification by countries. One of such sectors with the potential to influence every other sector of the economy as well as having the potential to be influenced by sectors of the economy it influences is the financial sector.

The financial sector is inextricably linked with most other sectors of the local economy as it finances development activity and contributes positively to the economy through financial intermediation activity. A functional financial sector promotes investment in productive sectors of the economy which may be potentially risky but have the potential of providing high returns to investment. Consequently, as the financial sector achieves progress it will inevitably realize development overtime. The importance of a developed financial sector has been highlighted by a number of studies (Levine, 1997; Rajan \& Zingales, 2003). Better mobilization of savings, dissemination of information about investment, optimizing the allocation of capital, mobilizing and pooling savings, and facilitating and encouraging foreign capital inflows are some of the outcomes of improved financial development (Kasekende, 2010), Thus financial development is appealing and from that perspective may be argued as a sine quo non for economic diversification of countries in general, and Sub-Saharan Africa countries in particular challenged with low levels of financial development due to low but relatively better developed banking sectors than capital markets.

A further driving force of economic diversification and indeed having a potential to drive progress in financial sector development is information and communications technology (ICT). A plethora of studies highlight ICT to play an important role for promoting economic growth and development (Ukwuoma, 2019; Andrianaivo and Kpodar, 2012; Nasab and Aghaei, 2009). Further, through the promotion of financial development as argued by studies as Al-Shubiri et al (2019) and Edo, Okodua and Odebiyi (2019) ICT may be argued to promote economic progress including economic diversification. ICT contributes to cost reduction of financial intermediation services, including commercial banks and microfinance institutions that will as a result be able to expand business activity. This is consistent with the argument that ICT diffusion has substantially improved the efficiency of resources allocation, enormously reduced production costs and promoted much greater demand and investment in all economic sectors as argued in the ICT and economic growth literature (Jorgenson and Stiroh 1999; Vu 2011; Lee, John and Luis 2012; Grimes, Cleo and Philip, 2012; Pradhan, Arvin and Norman, 2015).

Various ICT infrastructure may be identified to be linked with the promotion of financial development amongst which are Broadband, mobile cellular subscriptions, internet, secure servers, personal computers, fixed line telephones (World Bank, 2018; ITU, 2018). Over the years, ICT based technologies such as mobile payments, transactions, social networks and so on have plunged the financial sector into a higher dimension which is fast leading to the improvement of financial development across nations. According to World Bank (2018), aiding financial development is the availability of the internet which has been used to promote easier access to financial services, especially through enabling electronic banking. Instances exist where ICT has had significant impact on the financial sector of countries of the world. For example, digital devices such as the internet has enabled the provision of financial services which has become the new way of availing the unbanked population more opportunities of partaking in the formal financial system. Thulani, Chitakunye and Chummun (2014) highlights that the use of mobile money services has increased the access of people in both the rural and urban areas to financial products and services at reasonable costs.

Further the World Bank (2016) highlights African countries as having recorded impressive performance as regards mobile phone accounts and mobile phone transactions which contributed to improvement in mobile-phone based financial development of African countries. As at 2014, Sub-Sahara Africa's mobile-phone based financial development indicators of mobile phones, senders of remittances via a mobile phone as a percentage of senders and receivers of remittances via a mobile phone as a percentage of remittance recipients, was in multiples of that of other country regions such as South Asia, East Asia and Pacific, Europe and Central Asia, and Middle east. 
Therefore on the basis of the above, it is the case that there exists potential for SSA countries to realize their much soughtafter economic diversification through improving financial development, while at the same time harnessing the potentials of ICT for both financial development as well as economic diversification. The prospects of economic diversification in SSA countries, in addition to the abundance of natural resources including labour in the vast majority of the countries lies in higher mobile phone development relative to internet use, but with both internet use and mobile cellular subscriptions as measures of ICT rapidly rising overtime. Further financial development indicators of which the major ones respectively are private sector domestic credit to Gross domestic product measuring financial widening, and broad money supply to GDP measuring financial deepening while at varied levels across SSA countries are rising in general as financial reforms aimed at promoting financial development has been taking place in respective SSA countries. This study consequently explores the role of ICT and financial development for economic development in a panel of SSA countries. Previous studies relating ICT and financial development to economic diversification are limited amongst which are Adeola and Evans (2017) and lyoboyi and Na-Allah (2014). However the studies focused on a smaller set of countries relative to the panel of SSA countries that this study intends to examine, and also often utilized one measure of financial development without focusing on other measures of financial development. In addition, studies on ICT and financial development as Edo et al (2019) and Al-Shubiri et al (2019) did not examine economic diversification, while Ejemeyovwi and Osabuohien (2018) in examining inclusive growth in West Africa do not find a significant influence of mobile technology. This present research consequently is a novel study as it is the first study to explore the roles of both ICT and financial development for economic diversification in Sub-Saharan Africa, combining the strands of research on ICT and financial development, ICT and economic diversification, and financial development and economic diversification. Hence this study makes a significant contribution to the ICT, financial development and economic diversification literature

This present section having introduced the study, the study unfolds over the remaining five sections of the study with relevant literature discussed in the next section and theoretical framework and methodology discussed in section 3 . In section 4 , results of data analysis and their discussion are done while recommendations resulting from findings, and conclusions drawn from the study are presented in the final section of the study.

\section{Literature Review}

Information and Communications Technology (ICT) is linked to a wide array of economic and social variables as observed from the ICT literature. ICT has been linked to economic growth in the much discussed leap-frogging hypothesis (Adeleye et al, 2019), where ICT is argued to provide developing countries with an advantage in achieving economic development by enabling the countries to by-pass some of the difficult stages of development that developed countries of today passed through. Variety of channels exists through which ICT can influence growth and development and which have informed recent research related to ICT and financial development.

Andrianaivo and Kpodar (2012) assessed the impact of mobile phone penetration and financial inclusion on economic growth for a sample of 44 African countries from 1988 to 2007. The result of the system generalized method of moments (GMM) shows that the development of mobile phones influences economic growth. The interactions between the variables also show that mobile phone penetration and financial inclusion positively and significantly influence growth in Africa. Similarly, Nasab and Aghaei (2009) assessing the effect of ICT on economic growth in 7 OPEC countries covering the period 1990 to 2007 and using both fixed and random effect analysis, as well as generalized method of moments, established that ICT has a positive effect on economic growth in the countries.

Furthermore, Solarin, Shahbaz, Khan, and Razali (2019) using quarterly data from Malaysia from 1990 to 2015 examined the effect of information and communication technology, financial development, and economic growth on electricity consumption. The result shows that there exists a long-run relationship between the variables. Also, ICT, financial development, and economic growth influence electricity consumption positively. The causality test also shows the existence of a bidirectional relationship between financial development and electricity consumption, economic growth and electricity consumption, ICT and electricity consumption 
Asongu and Nwachukwu (2019) using the generalized method of moments examined the effect of ICT on financial sector development in 53 African countries for the period of 2004 -2011. The result shows that financial activity decline as a result of the relationship between ICT (represented by mobile phone and internet use) and formal financial development while an increase exists in financial activity as a result of the interaction between ICT and informal financial development. However the study omits other measures of ICT as fixed line telephones, secure internet servers, fixed broadband and ICT imports.

Further Alshubiri, Jamil and Elheddad (2019) using internet users and fixed broadband as a proxy for ICT examines the effect of ICT on financial development in six Gulf Cooperation Council (GCC) countries. The study adopted both fixed effect and generalized method of moments in achieving the objectives of the study covering the period 2000-2016. The result shows that both proxies for ICT positively and significantly influences both proxies of financial development (domestic credit to private sector as a percentage of gross domestic product (GDP) and broad money supply/GDP) but in varying proportion. The study also established that trade openness and urbanization affect financial development positively and significantly. However the study as with that of Asongu et al (2019) use limited ICT measures as they only use broadband and internet while omitting other ICT measures. Similarly, Edo, Okodua and Odebiyi (2019) find in a comparative study of Kenya and Nigeria using dynamic ordinary least squares and Vector Error Correction Model find that internet adoption is significant for raising the level of financial development. Financial development was measured using private sector domestic credit to Gross Domestic Product (GDP). This study in variance with previous similar studies surveyed used a single ICT indicator.

Financial development may contribute to an economy through enabling economic diversification and this is as highlighted by Adeola and Evans (2017) who using fully modified least square approach examined the effect of financial development and financial inclusion (measured by financial usage and access) on economic diversification of Nigeria from 1981 to 2014 . The Shannon index of economic diversification was used for the study and the result of the study showed that although financial inclusion and financial development positively affect economic diversification only financial inclusion has a significant impact on economic diversification. Also, the study examined the effects of some other variables like GDP per capita, capital formation on economic diversification but ICT variables is not included in the analysis, which is a gap this study intends to fill. However this study represents one of limited studies linking financial development to economic diversification.

lyoboyi and Na-Allah (2014) examined the relationship between information and communication technology (ICT) growth and diversification in Nigeria with particular reference to entertainment industry using quarterly data from 2010 to 2013 . The result of the ordinary Least Squares (OLS) and the Fully Modified Ordinary Least Squares (FMOLS) approach adopted shows that ICT enhances diversification and growth in the entertainment industry. The result also shows that the entertainment industry is a form of diversification in Nigeria's economy. However the entertainment industry represents one of many industries in a country and the study does not highlight the contribution of ICT to other industries.

\section{Methodology}

This study is founded on economic development theory, in which economic diversification is viewed as driven by simultaneous changes in production, consumption and trade patterns (Schuh and Barghouti,1988; Barghouti et al., 1990; and Petit and Barghouti, 1992). Through the faster growth of sectors with high income elasticity of demand in addition to forces of unbalanced growth, economic diversification may be driven. Hence in the context of Sub-Saharan Africa and based on the arguments of this study, both ICT and financial development, working together drive the process of economic diversification.

Equation (1) is the general model specification for this study adapted from Andriannaivo and Kpodar (2012)

ECODIV= $f(I C T$, FINDEV, FININC, RLAW, GEXP, TROPEN, PSE, L, K, INF) (1)

Where, ECODIV= Economic diversification, ICT = information and Communications Technology, FINDEV = Financial development, FININC = Financial inclusion, RLAW = Rule of Law, GEXP= government expenditure, TROPEN = Trade Openness, PSE = Primary School Enrollment, L = Labour, K = Capital, INF = Inflation. 
Economic diversification measure in this study is the Herfindahl-Hirschman index which is computed for this study. The index measures the concentration of the sectors in the total output of a country and while having a range between zero and one, values closer to one reflect lower diversification and vice versa. ICT indicators in this study are fixed broadband subscriptions (FIXEDBB), Fixed Telephone Subscriptions (FIXEDTSP), ICT good imports (ICTGIMPOT), Internet users (INTUSE), Mobile use (MOBUSE), and secure internet servers (SINTERNET) and rise in the indicators reflect higher levels of ICT development and vice versa. Financial development indicator used was private sector domestic credit to GDP ratio while financial inclusion indicator used was commercial bank branches per 100000 people. Hence equation (2) results.

$\mathrm{HHI}=f(F I X E D B B$, FIXEDTSP, ICTGIMPOT, INTUSE, MOBUSE, SINTERNET, FINDEV, FININC, RLAW, GEXP, TROPEN, PSE, L, K, INF) (2)

Explicitly expressing equation (2) above and log-transforming large variables to ensure standardized regression estimates, equation (3) results.

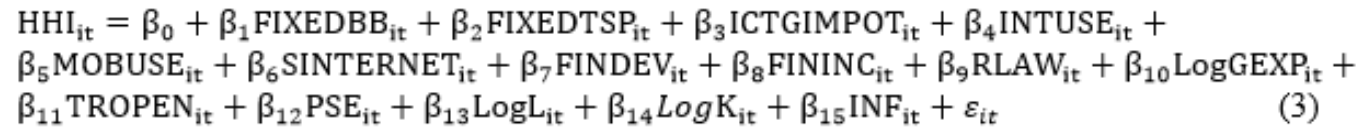

Where, $\mathrm{HHI}=$ Herfindahl-Hirschman index, FIXEDBB = Fixed Broadband subscriptions (per 100 subscribers), FIXEDTSP = Fixed Telephone Subscriptions (per 100 subscribers), ICTGIMPOT = ICT good imports (\% of total good imports), INTUSE = Internet users (per 100 subscribers), MOBUSE = Mobile subscriptions (per 100 subscribers), SINTERNET = secure internet servers, FINDEV = Financial development (in percentage), FININC = Financial inclusion (commercial bank branches per 100000 individuals), RLAW = Rule of Law (ranges between -2.5 and 2.5), GEXP= government expenditure (in Billions of US Dollars), TROPEN = Trade Openness (In percent), PSE = Primary School Enrollment (In Percentage), L = Labour (in Million), K $=$ Capital (In Billions of US Dollars), INF =Inflation (in percentage). $\epsilon=$ stochastic error term, $\mathrm{i}=$ country, $\mathrm{t}=$ time period. $\beta_{0}=$ constant, $\beta_{1}-\beta_{14}=$ marginal effects of independent variables. Log= Logarithm operand.

From equation (3) above, with the exception of rule of law which was sourced from the World Bank World Governance Indicators (WGI), all variables were sourced from the World Bank World Development Indicators (WDI). The model was estimated using Pooled Ordinary Least Squares regression, fixed effects estimation and two-step Generalized Method of Moments (GMM) estimation. The time frame covered by the data is between the year 2000 and 2019, while 37 of the 48 countries in sub-Sahara African (SSA) region form the sample. The selected countries are Botswana, Benin, Angola, Cabo Verde, Burkina Faso, Cameroon, Burundi, Comoros, Congo Republic, Cote d'Ivoire, Eswatini, Ethiopia, Gabon, Gambia, Ghana, Guinea, Guinea-Bissau, Kenya, Lesotho, Madagascar, Malawi, Mali, Mauritania, Mauritius, Mozambique, Namibia, Niger, Nigeria, Rwanda, Senegal, South Africa, Sudan, Tanzania, Togo, Uganda, Zambia and Zimbabwe. The selection of these countries is primarily premised on the extent of data availability.

\section{Results}

Table 1 presents the results of descriptive analysis of data used for this study. 
Table 1

Descriptive Statistics of Variables

\begin{tabular}{|c|c|c|c|c|c|c|c|c|}
\hline & $\mathrm{HH} \mathrm{I}^{\mathrm{e}}$ & FIXEDBB $^{a}$ & FIXEDTSPa & ICTGIMPOT' & INTERUSE ${ }^{\mathrm{a}}$ & MOBUSE & SINTERNET ${ }^{d}$ & FINDEV ${ }^{a}$ \\
\hline Mean & 0.374 & 0.487 & 2.804 & 3.935 & 10.038 & 49.102 & 145.712 & 22.502 \\
\hline Median & 0.366 & 0.062 & 0.950 & 3.536 & 4.500 & 40.604 & 3.943 & 14.804 \\
\hline Maximum & 0.636 & 21.639 & 34.273 & 12.774 & 62.000 & 163.875 & 14353.11 & 160.125 \\
\hline Minimum & 0.261 & 0.0001 & 0.000 & 0.595 & 0.015 & 0.000 & 0.000 & 0.403 \\
\hline Std. Dev. & 0.063 & 1.889 & 5.331 & 2.079 & 12.814 & 42.521 & 1158.825 & 25.909 \\
\hline Skewness & 1.152 & 7.998 & 3.776 & 1.273 & 1.872 & 0.647 & 10.102 & 3.199 \\
\hline Kurtosis & 5.013 & 74.799 & 18.512 & 4.979 & 6.136 & 2.468 & 107.700 & 13.992 \\
\hline \multirow[t]{2}{*}{ Obs. } & 740 & 740 & 740 & 740 & 740 & 740 & 740 & 740 \\
\hline & FININC & RLAWe & GEXPb & TROPEN ${ }^{\mathrm{a}}$ & $\operatorname{LLABOR}^{\mathrm{C}}$ & $K^{b}$ & $\mathrm{INF}^{\mathrm{a}}$ & \\
\hline Mean & 4.917 & -0.579 & 4.11 & 68.784 & 7.92 & 6.73 & 6.927 & \\
\hline Median & 3.252 & -0.598 & 1.42 & 60.332 & 4.97 & 2.15 & 5.041 & \\
\hline Maximum & 35.051 & 1.077 & 82.71 & 175.798 & 59.87 & 85.75 & 98.224 & \\
\hline Minimum & 0.136 & -1.852 & 0.0387 & 19.101 & 0.128 & 0.0242 & -60.496 & \\
\hline Std. Dev. & 5.382 & 0.598 & 10.51 & 31.531 & 10.64 & 13.63 & 8.878 & \\
\hline Skewness & 2.996 & 0.435 & 5.20 & 0.976 & 2.70 & 3.55 & 2.365 & \\
\hline Kurtosis & 13.927 & 2.868 & 32.20 & 3.492 & 10.92 & 15.89 & 27.122 & \\
\hline Obs. & 740 & 740 & 740 & 740 & 740 & 740 & 740 & \\
\hline \multicolumn{9}{|c|}{ Source: Authors Computation, 2020} \\
\hline \multicolumn{9}{|l|}{ Notes: } \\
\hline \multicolumn{9}{|c|}{ a: Figures in percentage } \\
\hline \multicolumn{9}{|c|}{ b: Figures in Billions of US Dollars } \\
\hline \multicolumn{9}{|c|}{ c: Figures in Million } \\
\hline \multicolumn{9}{|c|}{$\mathrm{d}$ :figures per 1 million } \\
\hline e: In decim & figures & & & & & & & \\
\hline
\end{tabular}

From Table 1, the mean values of all indicators are low reflecting the low level of development in general of Sub-Saharan Africa countries. Fixed telephone subscriptions per 100 (FIXEDTSP), mobile subscriptions per 100 (MOBILES) and number of secure internet servers per 1 million people (SINTERNET) have minimum values of zero indicating that no fixed telephone subscriptions per 100, no mobile subscriptions per 100 and no secure internet servers per 1 million people were recorded in sample countries

Maximum values of Herfindahl-Hirschman index $(\mathrm{HHI})$ of 0.636 reflects the low level of diversification of Sub-Sahara Africa countries. However maximum values for mobile subscriptions per 100 (MOBUSE), Secure internet servers per 1 million people (SINTERNET), financial development measured by private sector domestic credit to GDP ratio (FINDEV) and Trade Openness in percentage (TROPEN) of 163.88, 14353.11, 160.13, 175.80, reflect that some of sample SSA countries recorded impressive 
levels of the respective indicators over the period of focus of this study. Rule of law on the other hand, with a maximum value of 1.077 and a minimum of -1.852 reflects the poor quality of institutions prevalent in Sub-Saharan Africa countries.

From the measures of dispersion (standard deviation, skewness and kurtosis), standard deviation values show the spread of the data in each variable about their mean values. In Table 1, the standard deviation values are generally low as it ranges between 0.063 (for economic diversification; HHI) and 42.521 (for mobile subscriptions per 100; MOBUSE), except that of the number of secure internet servers per 1 million people (SINTERNET), which is 1158.825. Also, the skewness results revealed that most of the variables are positively skewed, while only three (Capital (K), Labour (L) and primary school Enrolments $(P S E))$ are negatively skewed. In the case of kurtosis, all the series in the variables exhibited kurtosis values greater than +1 , implying that the data distributions are picked.

\section{Effect of ICT and Finance on Economic Diversification}

The diversification of the economies of sub-Sahara African (SSA) countries, as the dependent variable, is the focus of this section. The impacts of the ICT variables [mobile subscriptions per 100 (MOBILES), the number of secure Internet servers per 1 million people (SINTERNET), internet users per 100 (INTERUSE), fixed broadband per 100 (FIXEDBB), fixed telephone subscriptions per 100 (FIXEDTSP), and ICT goods imports percentage of total goods imports (ICTGIMPOT)] and finance variables [financial developments (FINDEV) and financial inclusion (FININC)] on economic diversification (HHI) are estimated. Other engaged explanatory variables are the control variables. Four models are estimated using three estimation techniques; Pooled Ordinary Least Square (Pooled OLS), Fixed Effect Model (FEM) and Two-Step System Generalized Method of Moments (2-Step System GMM). The essence of adopting more than one technique is the need for robustness check of the results. GMM is chosen as the main technique of estimation in this study because it is argued that it takes care of endogeneity issue of explanatory variables, it has large sample properties and it can be specified without including full data generating process (Hansen, 1982; 2007). The results of the estimation are reported in Table 3 and 5 percent level of significance is reckoned with.

From Table 3, models 1 and 2 are estimated using Pooled OLS and Fixed Effect Model (FEM) respectively, while models 3 and 4 are estimated with Two-Step System GMM. The results of model 1 revealed that all the explanatory variables significantly explained the diversification of the economies in SSA with F-statistic of 41.84824 ( $\mathrm{Pr} .=0.000<0.05)$. The adjusted R-square of model 1 showed that about 42 percent of variations in economic diversification is explained by the model. Similarly, model 2 results showed that all the explanatory variables significantly explained the diversification of the economies with F-statistic of $55.12373(\mathrm{Pr} .=0.000<0.05)$. The adjusted R-square of model 2 showed that about 79 percent of variations in economic diversification is explained by the model. Prior the choice of FEM, Hausman test on the choice of either Random 
Table 3

Analysis of the Effect of ICT and Finance on Economic Diversification

\begin{tabular}{|c|c|c|c|c|}
\hline \multicolumn{5}{|l|}{ Dependent Variable. HHI } \\
\hline \multirow[t]{2}{*}{ Method Used } & \multicolumn{2}{|c|}{ Panel Least Squares } & \multirow[t]{2}{*}{ 2-Step System GMM } & \\
\hline & Pooled OLS & Fixed Effect & & \\
\hline Independent Variables & Model 1 & Model 2 & Model 3 & Model 4 \\
\hline \multirow[t]{2}{*}{$\mathrm{HHI}(-1)$} & \multirow[t]{2}{*}{-} & \multirow[t]{2}{*}{-} & $0.877017 *$ & $0.8920345^{\star}$ \\
\hline & & & $(0.000)$ & $(0.000)$ \\
\hline \multirow[t]{2}{*}{ FIXEDBB } & 0.000117 & 0.001029 & 0.0002007 & 0.0001598 \\
\hline & $(0.9376)$ & $(0.3608)$ & $(0.255)$ & $(0.361)$ \\
\hline \multirow[t]{2}{*}{ FIXEDTSP } & $0.002717 *$ & 0.001967 & $0.0003884^{\star}$ & $0.0003114^{*}$ \\
\hline & $(0.0004)$ & $(0.2706)$ & $(0.003)$ & $(0.045)$ \\
\hline \multirow[t]{2}{*}{ ICTGIMPOT } & $0.002679 *$ & -0.000540 & $0.000495^{\star}$ & $0.0004875^{\star}$ \\
\hline & $(0.0166)$ & $(0.5478)$ & $(0.024)$ & $(0.009)$ \\
\hline \multirow[t]{2}{*}{ INTERUSE } & $0.000648^{*}$ & 0.000189 & -0.0000447 & -0.0000674 \\
\hline & $(0.0139)$ & $(0.3673)$ & $(0.158)$ & $(0.060)$ \\
\hline \multirow[t]{2}{*}{ MOBILES } & $-0.000325^{\star}$ & $0.000175^{\star}$ & -0.00000798 & 0.00000288 \\
\hline & $(0.0000)$ & $(0.0249)$ & $(0.398)$ & $(0.779)$ \\
\hline \multirow[t]{2}{*}{ SINTERNET } & 0.0000016 & -0.000000427 & 0.000000169 & 0.000000133 \\
\hline & $(0.3415)$ & $(0.6975)$ & $(0.126)$ & $(0.380)$ \\
\hline \multirow[t]{2}{*}{ FINDEV } & $0.000247 *$ & $0.000737 *$ & -0.00000218 & - \\
\hline & $(0.0490)$ & $(0.0006)$ & $(0.945)$ & \\
\hline \multirow[t]{2}{*}{ FININC } & 0.0000589 & $-0.006762^{*}$ & - & 0.0000188 \\
\hline & $(0.9195)$ & $(0.0000)$ & & $(0.793)$ \\
\hline \multirow[t]{2}{*}{ RLAW } & $-0.039751^{*}$ & $-0.026303^{*}$ & -0.0016182 & -0.0010844 \\
\hline & $(0.0000)$ & $(0.0001)$ & $(0.129)$ & $(0.333)$ \\
\hline \multirow[t]{2}{*}{ Log GEXP } & $0.018894^{*}$ & $0.015235^{\star}$ & $0.0033876^{*}$ & $0.0032634^{*}$ \\
\hline & $(0.0000)$ & $(0.0002)$ & $(0.001)$ & $(0.001)$ \\
\hline \multirow[t]{2}{*}{ TROPEN } & $0.000543^{*}$ & $-4.59 E-05$ & 0.0000314 & 0.0000172 \\
\hline & $(0.0000)$ & $(0.6243)$ & $(0.101)$ & $(0.421)$ \\
\hline \multirow[t]{2}{*}{ PSE } & $0.000320 *$ & $9.52 \mathrm{E}-05$ & $0.0000556^{*}$ & 0.0000399 \\
\hline & $(0.0003)$ & $(0.4562)$ & $(0.009)$ & $(0.045)$ \\
\hline \multirow[t]{2}{*}{ LLABOR } & $-0.022809 *$ & $-0.053333^{*}$ & $-0.0030645^{\star}$ & $-0.0030899 *$ \\
\hline & $(0.0000)$ & $(0.0004)$ & $(0.000)$ & $(0.000)$ \\
\hline
\end{tabular}




\begin{tabular}{|c|c|c|c|c|}
\hline \multicolumn{5}{|c|}{ Dependent Variable. HHI } \\
\hline \multirow[t]{2}{*}{ LK } & 5.79E-05 & $-0.010016^{*}$ & -0.0005887 & -0.0005112 \\
\hline & $(0.9866)$ & $(0.0141)$ & $(0.484)$ & $(0.492)$ \\
\hline \multirow[t]{2}{*}{ INF } & -0.000269 & -0.000173 & $-0.0000818^{\star}$ & $-0.0000876^{\star}$ \\
\hline & $(0.1852)$ & $(0.2655)$ & $(0.039)$ & $(0.031)$ \\
\hline \multirow[t]{2}{*}{ C } & $0.212578^{*}$ & $1.052710^{*}$ & $0.0218749 *$ & $0.020338^{*}$ \\
\hline & $(0.0000)$ & $(0.00000)$ & $(0.021)$ & $(0.004)$ \\
\hline R-squared & 0.464388 & 0.803390 & $A R(1)=-3.32(0.001)$ & $A R(1)=-3.38(0.001)$ \\
\hline Adj. R-squared & 0.453291 & 0.788816 & $\operatorname{AR}(2)=1.04(0.298)$ & $\operatorname{AR}(2)=1.05(0.295)$ \\
\hline \multirow[t]{2}{*}{ F-statistic } & 41.84824 & 55.12373 & $\mathrm{WT}=133368.84(0.000)$ & WT $=465030.24$ \\
\hline & $(0.000000)$ & $(0.000000)$ & & $(0.000)$ \\
\hline Durbin-Wat. stat & 0.211832 & 0.559059 & Instr. rank=51 & Instr. rank=51 \\
\hline Hausman Test & - & $46.39(0.000)$ & $\mathrm{HT}=12.05(0.797)$ & $\mathrm{HT}=11.52(0.828)$ \\
\hline \multicolumn{5}{|c|}{$\begin{array}{l}\text { NB: * indicates significance at } 5 \text { percent. Probability value in parenthesis. HT means Hansen Test of over-identified } \\
\text { restrictions. WT represents Wald chi-square test of model significance }\end{array}$} \\
\hline \multicolumn{5}{|c|}{ Source: Authors Computation, 2020} \\
\hline
\end{tabular}

or Fixed effect model was carried out with the null hypothesis that there is no misspecification in the random effect model. The Hausman test result rejected the null hypothesis $(\operatorname{Pr} .=0.000<0.05)$, we then accept the alternative hypothesis that there is misspecification in the random effect model. This imply adopting the fixed effect model (FEM) over the random effect. Models 3 and 4 are simply reporting the effects of financial developments and financial inclusion respectively on economic diversification in models with ICT variables among other control variables.

In models 3 and 4 as shown in Tables 3, the AR(1) and AR(2) represent the Arellano and Bond (1991) tests for first and second order serial correlation respectively. The null hypothesis tested in both is 'no serial correlation'. The results revealed that for both models $3 \& 4$, the null hypothesis of no first order [AR(1)=3.32 \& 3.38 for models $3 \& 4$ respectively] serial correlation is rejected, while the null hypothesis is accepted for the second order $[\operatorname{AR}(2)=1.04 \& 1.05$ for models $3 \& 4$ respectively] serial correlation at the 5 per cent level of significance. These results revealed that the system GMM estimates are consistent (Baltagi, 2005). Also, the instruments rank in both models is 51 each, which satisfy the condition that the rank of instruments in each model should be greater than the number of coefficients estimated (Roodman, 2006).

The findings from Hansen Test $(\mathrm{HT})$ of over-identified restrictions ( $\mathrm{p}$-values for models $3 \& 4$ are 0.797 and 0.828 respectively) showed that the instruments are valid, as this is a necessary condition for GMM estimates. The Wald Chi-square statistic of model significance revealed that the explanatory variables in models $3 \& 4$ significantly $[\mathrm{Pr}$. (WT) $=0.000$ in both models] explained the variation in economic diversification at 5 percent level of significance.

In models 3 and 4, the lagged values of Herfindahl-Hirschman Index [HHI(-1)] have positive and high level of statistical significance at 5 percent level of significance. A high value of the $\mathrm{HHI}$ and hence lower economic diversification in the previous year will also lead to lower level of economic diversification in the current year, but at a rate less than the previous year. Considering the effects of the ICT variables on the economic diversification measure, Herfindahl-Hirschman Index (HHI), fixed broadband per 100 (FIXEDBB) consistently exhibited positive impact on Herfindahl-Hirschman Index (HHI) in all the four models estimated, but the impacts are not statistically significant at 5 percent level of significance. Similarly, the number of 
secure internet servers per 1 million people (SINTERNET) positively impacted Herfindahl-Hirschman Index as revealed in models $1,3 \& 4$, but the impacts are not statistically significant. The fixed telephone subscriptions per 100 (FIXEDTSP) has positive and statistically significant ( $p$-values $=0.0004,0.003 \& 0.045$ ) effects on Herfindahl-Hirschman Index as shown in models $1,3 \& 4$ and hence is significant in reducing economic diversification. A unit increase in fixed telephone subscriptions per 100 will raise Herfindahl-Hirschman Index slightly (coefficient ranges between 0.0003 and 0.003 ) and hence result in a less diversified economy and vice versa.

In similar manner, ICT goods imports percentage of total goods imports (ICTGIMPOT) has positive and statistically significant (p-values $=0.0166,0.024 \& 0.009$ ) effect on Herfindahl-Hirschman Index (HHI) as found in models $1,3 \& 4$. A unit increase in ICT goods imports percentage of total goods imports will slightly (coefficient ranges between 0.0005 and 0.003 ) raise Herfindahl-Hirschman Index and hence consequently result in a less diversified economy in sample countries. Internet users per 100 (INTUSE) has negative and statistically insignificant (p-values= $0.156 \& 0.060$ ) effects on Herfindahl-Hirschman Index as shown in models $3 \& 4$ (the results of GMM is mainly of interest). In the case of mobile subscriptions per 100 (MOBUSE), the impact on economic diversification is inconsistent (negative in model 3, but positive in model 4) and statistically insignificant. Hence internet use is not significant for economic diversification. The general adverse effect of ICT on economic diversification as found in this study may be explained by poor connectivity of ICT in general in sub-Saharan Africa countries. Poor internet connectivity is a result of poor ICT infrastructure either on account of insufficient ICT investment for which the government is primarily responsible for the provision or the poor quality of ICT infrastructure provided. In addition, poor access to electricity which hinders the use ICT devices as highlighted by Owolabi et al (2020) may be argued as a factor giving rise to the adverse effect of ICT on economic diversification of Sub-Saharan Africa countries. Further the inability of individual to appropriately use ICT devices on account of poor literacy as highlighted by Chatterjee et al (2020) also explains the finding as regards ICT. Lastly most firms operating across sectors of SSA countries do not have an online presence and this may also explain the finding from this study of adverse effect of ICT on economic diversification.

The findings on the finance variables revealed that in model 3, financial development (FINDEV) has negative and statistically insignificant ( $\mathrm{p}$-value=0.945) effect on Herfindahl-Hirschman Index. In model 4, financial inclusion (FININC) on the other hand, has positive and statistically insignificant ( $p$-value $=0.793$ ) effect on economic diversification. This results imply that the financial variables are insignificant in promoting economic diversification in SSA. While the effect of financial development in promoting economic diversification in SSA is insignificant, that of financial inclusion discourages economic diversification although it is insignificant. The findings of this study contrast with that of Adeola and Evans (2017) and may reflect the rather low level of financial development in Sub-Saharan Africa countries. Despite series of financial sector reforms, financial development and inclusion which have the potential to drive economic diversification initiatives are failing to play their role. This may be on account of the poor state of enabling infrastructure as electricity, the rather large segments of the population especially in rural areas who are excluded from financial service provision, as well as low level of education of the public regarding the potentials of ICT for performing financial transactions and the financial products and services provided by financial institutions as highlighted by Chatterjee et al (2020).

In other results, Rule of law' ( $R L A W$ ) has negative and statistically insignificant ( $\mathrm{p}$-value=0.129 \& 0.333) effect on HerfindahlHirschman Index and hence is insignificant for boosting economic diversification in Sub-Saharan Africa as shown in models $3 \& 4$. In same manner, capital $(L K)$ has negative and statistically insignificant ( $p$-value $=0.484 \& 0.492$ ) effect on HerfindahlHirschman Index as shown in models $3 \& 4$. Both labour force (LLABOR) and inflation rate (INF) have negative and statistically significant effects on Herfindahl-Hirschman Index as revealed by the p-values 0.000 for labour and $0.039 \& 0.031$ for inflation in models $3 \& 4$ reflecting that the variables significantly boost economic diversification in Sub-Saharan Africa. These findings may imply that high inflation supports economic diversification in SSA possibly via the incentive to producers to produce output on account that they will realise massive revenues for their output from high prices. Labour force on the other hand is also encouraging for economic diversification too especially for countries as Nigeria that have a large labour force on account of their large population. On the other hand, government expenditure (LGEXP) has positive and statistically significant ( $p$-values $=0.000,0.0002 \& 0.001$ ) effects on Herfindahl-Hirschman Index in all the models estimated. A one (1) percent increase in government expenditure will slightly (coefficients ranges between 0.003 and 0.019 ) reduce Herfindahl- 
Hirschman Index and hence reduce economic diversification in SSA. Trade openness (TROPEM) has positive but statistically insignificant ( $p$-value $=0.101 \& 0.421$ ) effect on Herfindahl-Hirschman Index as shown in models $3 \& 4$, while primary school enrolment (PSE) has positive and statistically significant ( $p$-value $=0.009 \& 0.045$ ) effect on Herfindahl-Hirschman Index as shown in models $3 \& 4$. A unit increase in primary school enrolment will slightly (coefficient ranges between 0.00004 and 0.00006) raise Herfindahl-Hirschman Index and hence reduce economic diversification.

\section{Implications Of Findings}

This study on the basis of its findings gives rise to a number of implications. First, ICT and financial development may play an important role in the promotion of economic diversification for SSA countries. However this will require greater development in relation to ICT in a broad range of indicators as internet, broadband, ICT investment, ICT imports, fixed line telephone amongst other ICT devices, as well as the financial sector. Secondly if economic diversification is to become a reality in SSA countries, it will require fast paced and well-targeted financial sector reforms. Lastly, the costs of firms operating in various sectors across SSA countries for establishing an online presence need to be reduced, especially as many of the firms are of small and medium sizes, while access to ICT by individuals that will use such ICT devices must also be enhanced through reducing the cost of ICT devices such as cost of internet subscriptions in order that ICT may promote economic diversification in SSA countries.

\section{Recommendations And Conclusion}

This study on the basis of its findings, make a number of recommendations. First, Individuals in SSA countries should have improved access to ICT devices through reduction in cost of internet or mobile subscriptions as well as cost of ownership of ICT devices as mobile phones. Secondly, firms operating in sectors as across SSA countries, many of which are small and medium enterprises, should be supported in the cost of providing an online presence in order that the firms goods and services are easily accessible to individuals with access to ICT devices as mobile phones and internet. Thirdly, Governments of SSA countries should ensure adequate provision of quality ICT infrastructure so as to enhance internet connectivity which

will encourage the use of ICT devices for patronizing firms across the various sectors of SSA countries. Fourth, governments of SSA countries should promote greater access to electricity for all so that ICT devices can be used to patronize firms in sectors of SSA countries while the firms are incentivized to be present on online mediums for customers to patronize them. Finally, greater literacy rates of the population should be promoted in SSA countries so that individuals are aware of how they may use ICT devices to patronize firms in sectors of SSA countries.

In conclusion, economic diversification has long been argued for SSA countries amongst which are countries as Nigeria which has for long depended on crude oil. This study has investigated the impacts of ICT and financial development on economic diversification. The findings revealed that a high level of economic diversification in the previous year leads to a high level of economic diversification in the current year, but at a rate less than the previous year. Also, 'fixed broadband per 100 ' and 'the number of secure internet servers per 1 million people' adversely affected economic diversification but insignificantly. Fixed telephone subscriptions per 100' and 'ICT goods imports percentage of total goods imports' significantly contributed to reducing economic diversification. Internet users per 100 and mobile subscriptions per 100 were insignificant for boosting economic diversification. The study further revealed financial inclusion is insignificant in reducing economic diversification in SSA, while financial developments is insignificant for boosting economic diversification. Our results are robust to alternative model estimations

\section{Declarations}

\section{Availability of Data and Materials}

The datasets used and analysed during the current study are available from World Bank [https://databank.worldbank.org/source/world-development-indicators] and

Page $12 / 14$ 
[https://databank.worldbank.org/source/worldwide-governance-indicators]

\section{Competing interests}

The authors declare that they have no competing interests.

\section{Funding}

Not Applicable

\section{Authors' Contributions}

OAO conceptualizing the idea and writing, AOA data analysis and writing, BA conceptualizing the idea and writing, AOO conceptualizing the idea, Ogunbiyi T. All authors read and approved the final manuscript.

\section{Acknowledgements}

The authors appreciate the reviewers of this manuscript for their thorough review and suggestions

\section{References}

1. Adeola O, Evans O (2017) Financial Inclusion, Financial Development, and Economic Diversification in Nigeria. The Journal of Developing Areas 51(3):2-15

2. Adeleye N, Eboagu C (2019) Evaluation of ICT development and economic growth in Africa. NETNOMICS: Economic Research Electronic Networking 20(1):31-53

3. Alshubiri F, Jamil SA, Elheddad M (2019) The impact of ICT on financial development: Empirical evidence from the Gulf Cooperation Council countries. International Journal of Engineering Business Management 11:1-14

4. Andrianaivo M, Kpodar K (2012) Mobile Phones, Financial Inclusion, and Growth. Review of Economics Institutions $3(2): 1-30$

5. Arellano M, Bond S (1991) Some Test of Specification for Panel Data: Monte Carlo Evidence and an Application to Employment Equations. Rev Econ Stud 58:277-297

6. Asongu SA, Nwachukwu JC (2019) ICT, financial sector development and financial access. Journal of the Knowledge Economy 10(2):465-490

7. Baltagi BH (2005), Econometric Analysis of Panel Data, 3rd edition, John Wiley \& Sons Ltd., West Sussex, England

8. Edo S, Okodua H, and Odebiyi J (2019) Internet Adoption and Financial Development in Sub-Saharan Africa: Evidence from Nigeria and Kenya. Afr Dev Rev 31(1):144-160

9. Ejemeyovwi JO, Osabuohien ES (2018) Investigating the relevance of mobile technology adoption on inclusive growth in West Africa. Contemporary Social Science

10. Grimes A, Cleo R, and Philip S (2012) The need for speed: Impacts of internet connectivity on firm productivity. J Prod Anal 37:187-201

11. Hansen LP (1982) Large Sample Properties of Generalized Method of Moments Estimation. Econometrica 50:10291054

12. Hansen LP (2007) Generalized Method of Moments Estimation. University of Chicago, palgrave

13. International Telecommunications Union (2017) ICT Facts and Figures 2017. International Telecommunication Union, Geneva

14. Iyoboyi M, Na-Allah A (2014) ICT-Driven Growth and Diversification: The Case of Nigeria's Entertainment Industry. Journal of Economics Development Studies 2(4):255-268

15. Jorgenson DW, Stiroh KJ (1999) Information technology and growth. Am Econ Rev 89(2):109-115 
16. Kasekende L (2010) Developing a sound banking system in Sub-Sahara African countries. in African Finance in the 21st Century, ed. by M. Quintyn and G. Verdier

17. Levine R (1997) Financial development and economic growth: views and agenda. JEconLit 35:688-726

18. Nasab EH, Aghaei M (2009).The Effect of ICT on Economic Growth: Further Evidence. International Bulletin of Business Administration, issue 5, pp.45-56

19. OECD (2011), Economic Diversification in Africa: A Review of Selected Countries, OECD Publishing

20. Owolabi OA, Oku AO, Alejo A, Ognbiyi T, Ubah JI (2020) Access to electricity, Information and Communications Technology, and financial development: Evidence from West Africa. International Journal of Energy Economics Policy. Forthcoming

21. Pradhan RP, Arvin MB, Norman NR (2015) The dynamics of information and communications technologies infrastructure, economic growth, and financial development: Evidence from Asian countries. Technol Soc 42:135-149

22. Roodman D (2006), "How to Do xtabond2: An Introduction to "Difference" and "System" GMM in Stata," Working Papers 103, Center for Global Development

23. Solarin SA, Shahbaz M, Khan HN, Razali RB (2019) ICT, Financial Development, Economic Growth and Electricity Consumption: New Evidence from Malaysia. Global Business Review 1-22

24. Thulani M, Chitakunye P, Chummun BZ (2014) Mobile money as a strategy for financial inclusion in rural communities. Mediterranean Journal of Social Sciences 5(25):216-216

25. Ukwuoma HC (2019) The Effect of ICT on Economic Growth in Nigeria. International Journal of Management, Technology and Engineering, Vol. IX, Issue II: pp. 2292-2302

26. Vu KM (2011) ICT as a source of economic growth in the information age: Empirical evidence from the 1996-2005 period. Telecommunications Policy 35:357-372

27. World Bank (2016) Financial Inclusion Data: Global Findex. World Bank, Washington, DC

28. Zagros MS (2016) What is the definition of economic diversification? Available online at https://www.quora.com/Whatis-the-definition-of-economic-diversification

\section{Table}

Table 2 is not available with this version. 